\title{
The Ethanol Crude Extraction of Cyperus Rotundus Regulates Apoptosis-associated Gene Expression in HeLa Human Cervical Carcinoma Cells In Vitro
}

\author{
CHIA-HSIN LIN ${ }^{1}$, SHU-FEN PENG ${ }^{2,3}$, FU-SHIN CHUEH ${ }^{4}$, ZHENG-YU CHENG ${ }^{3}$, \\ CHAO-LIN KUO $^{1 *}$ and JING-GUNG CHUNG ${ }^{3,5^{*}}$ \\ ${ }^{I}$ Department of Chinese Pharmaceutical Sciences and Chinese Medicine Resources, \\ China Medical University, Taichung, Taiwan, R.O.C.; \\ ${ }^{2}$ Department of Medical Research, China Medical University Hospital, \\ China Medical University, Taichung, Taiwan, R.O.C.; \\ ${ }^{3}$ Department of Biological Science and Technology, China Medical University, Taichung, Taiwan, R.O.C.; \\ ${ }^{4}$ Department of Food Nutrition and Health Biotechnology, Asia University, Taichung, Taiwan, R.O.C.; \\ ${ }^{5}$ Department of Biotechnology, Asia University, Taichung, Taiwan, R.O.C.
}

\begin{abstract}
Background/Aim: Cervical cancer is considered poorly chemo-sensitive in women and its treatment remains unsatisfactory. Cyperus rotundus is used in Chinese medicine as a therapeutic agent for women's disease. The effects and molecular mechanisms of the ethanol extraction of C. rotundus (CRE) on cervical cancer remain unclear. We aimed to explore the mechanisms and genetic influence of CRE on cervical cancer. Materials and Methods: HeLa, human cervical cancer cells were treated with various doses of CRE and changes in cell morphology and cell viability were assessed using microscopy and flow cytometry. Finally, we performed a microarray analysis to scan related genes. Results: The treatment of CRE on HeLa cells caused morphological changes and induced chromatin condensation. DNA microarray analysis showed that CRE led to up-regulation of 449 genes and downregulation of 484 genes, which were classified in several
\end{abstract}

This article is freely accessible online.

*These Authors contributed equally to this work.

Correspondence to: Jing-Gung Chung, Department of Biological Science and Technology, China Medical University, No 91, HsuehShih Road, Taichung 404, Taiwan, R.O.C. Tel: +886 4 22053366, ext. 8000, Fax: +886 4 22053764, e-mail: jgchung@mail.cmu.edu.tw and Chao-Lin Kuo, Department of Chinese Medicine Resources, China Medical University, No 91, Hsueh-Shih Road, Taichung 404, Taiwan, R.O.C. Tel: +886422053366 ext. 5202, Fax: +886 422053764 e-mail: clkuo@mail.cmu.edu.tw

Key Words: Cyperus rotundus, cervical cancer, HeLa cells, apoptosis, gene expression. interaction pathways. Conclusion: CRE changed HeLa cell morphology and induced gene expression which associated with apoptosis and cell-cycle arrest. These results provide important information at the transcription level for targeting treatments of human cervical cancer.

Cyperus rotundus L. (Cyperaceae) has been extensively used in traditional medicine in Asia, Africa, and Europe. It is also known as nutgrass and is cultivated widely in tropical, subtropical and temperate regions. It is prescribed for gynecological disorders, including dysmenorrhea and irregular menstruation, while its rhizomes (rootstalks) have been used as sedatives and analgesics $(1,2)$. Recently, many studies have demonstrated that its rhizomes have a vast range of biological and pharmacological functions, including anti-oxidant, antiinflammatory, anti-diabetic, anti-allergic, anti-nociceptive and anti-cancer effects (2-4). The active chemical constituents of $C$. rotundus are saponins, alkaloids, flavonoids (anthocyanidins, catechins, flavans, flavones, flavanonols, and isoflavane), tannins, starch, glycosides, terpenoids, sesquiterpenes, sitosterol, cyperol, ascorbic acid, polyphenols, and essential oils ( $\alpha$ longipinane, $\beta$-selinene, cyperene, and caryophyl leneoxide) ( 2 , $5,6)$. Recently, the $C$. rotundus rhizome extract exhibited a protective effect against attenuated peroxynitrite (ONOO-)induced neurotoxicity (6) and also prevented DNA damage and cytotoxicity through its antioxidant activity in human neuroblastoma SH-SY5Y cells (7).

Moreover, the anticancer properties of $C$. rotundus have been a focus of research recently. The essential oil isolated from $C$. rotundus can suppress cell proliferation and induce apoptotic DNA fragmentation in murine lymphoblastic leukemia L1210 cells and human chronic myelogenous leukemia K562 cells (4, 
8). The apoptotic activity of the different fractions of $C$. rotundus extract has been examined in the treatment of MDA-MB-231 breast cancer. The ethanolic/methanolic extracts display an anti-proliferative activity and induce apoptosis through increased expression of the death receptor, such as TNF- $\alpha$, IFN- $\gamma$, and MAPK, while inhibiting the expression of the anti-apoptotic factor survivin. On the contrary, the water extract displayed no such properties $(2,9)$.

Cervical cancer is a major cause of morbidity in women worldwide, with a poor chemo-sensitivity to therapy (10). The role of chemotherapy in the treatment of cervical cancer has mainly been confined to persistent or recurrent cases following failure of surgery and/or radiotherapy. Cisplatin represents the cornerstone of chemotherapy for cervical cancer, however, it has a limited efficacy due to its side-effects and the development of resistance. The induction of apoptosis has been shown to be an efficent strategy for identifying potential therapeutic agents for cancer therapy (11).

The effects and related molecular mechanism of $C$. rotundus extract properties on cervical cancer are not really understood. Our aim, herein, was to evaluate the anti-cancer effects of Cyperus rotundus in vitro, including its cytotoxic effect and how it affects gene expression in HeLa human cervical cancer cells.

\section{Materials and Methods}

Chemicals and reagents. Cyperus rotundus $\mathrm{L}$. was planted in Taiwan (Figure 1A) and its rhizomes (Figure 1B) were purchased from Lian He Pharmacy (Taichung, Taiwan, R.O.C.). Ethanol (95\%) was obtained from Echo Chemical Co. LTD (Taichung, Taiwan). DMEM medium, fetal bovine serum (FBS), L-glutamine, and antibiotics (penicillin $G$ and streptomycin) were purchased from Gibco BRL (Grand Island, NY, USA), DAPI from Molecular Probes (Eugene, OR, USA), and trypsin and propidium iodide (PI) from Sigma Chemical Co. (St. Louis, MO, USA). The crude extraction of Cyperus rotundus L. (CRE) was conducted using 95\% Ethanol.

Cell culture. HeLa cells, a well-known human cervical cancer cell line, was obtained from the Food Industry Research and Development Institute (Hsinchu, Taiwan, R.O.C.). HeLa cells were maintained in DMEM medium supplemented with FBS $(10 \%)$, L-glutamine $(1 \%)$, and penicillin G/streptomycin (100 Units $/ \mathrm{ml} / 100 \mu \mathrm{g} / \mathrm{ml}$ ) and were maintained in a $37^{\circ} \mathrm{C}$ incubator under $5 \% \mathrm{CO}_{2}$ and $95 \%$ air (12).

Observation of cell morphology and measurement of cell viability. HeLa cells $\left(2 \times 10^{5}\right.$ cells/well) were placed in 12 -well plates overnight and were then treated with: i) 100 , ii) 200 , iii) 300 , iv) 400 , and v) 500 $\mu \mathrm{g} / \mathrm{ml}$ of CRE for 48 hours. Following treatment, cell morphology was observed and photographed using a phase contrast microscope (Carl Zeiss, Axiovert 25, Oberkochen, Germany) at 200x magnification and cells were detached by trypsin, subsequently wash by PBS (phosphate buffered saline), and collected in FACS tube. This was followed by PI staining $(5 \mu \mathrm{g} / \mathrm{ml})$ for cell viability using flow cytometry (BectonDickinson, San Jose, CA, USA) as described previously (13) .
DAPI nuclear staining. The effects of apoptosis, chromatin condensation and the presence of apoptotic bodies were investigated using DAPI staining. Following treatment with the aforementioned concentrations of CRE, HeLa cells were immersed in $4 \%$ paraformaldehyde for $15 \mathrm{~min}$, stained with DAPI $(1 \mu \mathrm{g} / \mathrm{ml})$ for 30 min at room temperature and, then the morphology of nucleus was visualized and photographed using a fluorescence microscope (Carl Zeiss, Axiovert 25, Oberkochen, Germany) at 100× magnification. Cells with condensed, fragmented and degraded nuclei were recognized as apoptotic cells (14). When cells undergo apoptosis, there is enhanced fluorescent signals in the nucleus. Ten nuclei of cells were randomly selected to quantify the fluorescence intensity of DAPI signals by using the NIH Image J software, version 1.47 (National Institutes of Health, Bethesda, MA, USA).

Generation of cDNA microarray, hybridization, and scanning for gene expression in HeLa cells following exposure to CRE. HeLa cells $\left(6 \times 10^{5}\right.$ cells/dish) were sub-cultured in $10-\mathrm{cm}$ dish for $24 \mathrm{~h}$. Then cells were treated with CRE $(300 \mu \mathrm{g} / \mathrm{ml})$ or not (control) for $48 \mathrm{~h}$. Total RNA was extracted and purified using the Qiagen RNeasy Mini Kit (Qiagen, Inc, Valencia, CA, USA), according to manufacturer's instructions. Subsequently, cDNA was reverse transcribed from extracted RNA and then fluorescently-labeled for probe preparation. Fluorescence-labeled cDNAs were probed to their complementary strands on the chip (Affymetrix GeneChip Human Gene 1.0 ST array, Affymetrix, Santa Clara, CA, USA) and the hybridization signals were examined and quantified by Asia BioInnovations Corporation (Taipei, Taiwan, ROC). Finally, the difference of data was analyzed using the Expression Console software (Affymetrix) with default RNA parameters. Genes up- or down-regulated by at least 2-fold in CRE-treated cells compared to controls were recorded. Data are representative from three separate assays (15).

Gene ontology analysis. For detecting significantly over-represented GO (Gene Ontology) biological processes we used DAVID (Database for Annotation, Visualization and Integrated Discovery), that provides an overall set of functional annotation tools for researchers to know biological meaning behind large list of genes. Enrichment was determined at a calculated Benjamini value of $<0.05$. Statistical significance of overexpressed individual genes was determined using a standard Student's $t$-test.

Statistical analysis. Experimental values are expressed as mean \pm standard deviation (SD) from three independent experiments, each conducted in triplicates. Statistical significance $\left({ }^{*} p<0.05\right.$, $*^{*} p<0.01$, and $\left.* * * p<0.001\right)$ was assessed using one-way ANOVA and Tukey multiple comparison test for comparing CRE-treated groups to the control (16).

\section{Results}

CRE induced cell morphological changes and decreased viable HeLa cells in vitro. At first, we assessed the cell viability of HeLa cells following exposure to CRE. As shown in Figure 2A, CRE treatment at high concentrations $(200-500 \mu \mathrm{g} / \mathrm{ml})$ significantly decreased cell viability and caused morphological changes in HeLa cells in a concentration-dependent manner (Figure 2B). CRE-treated cells showed shrunken, deformed, and small vacuoles appear inside cells. The half-maximal 
A

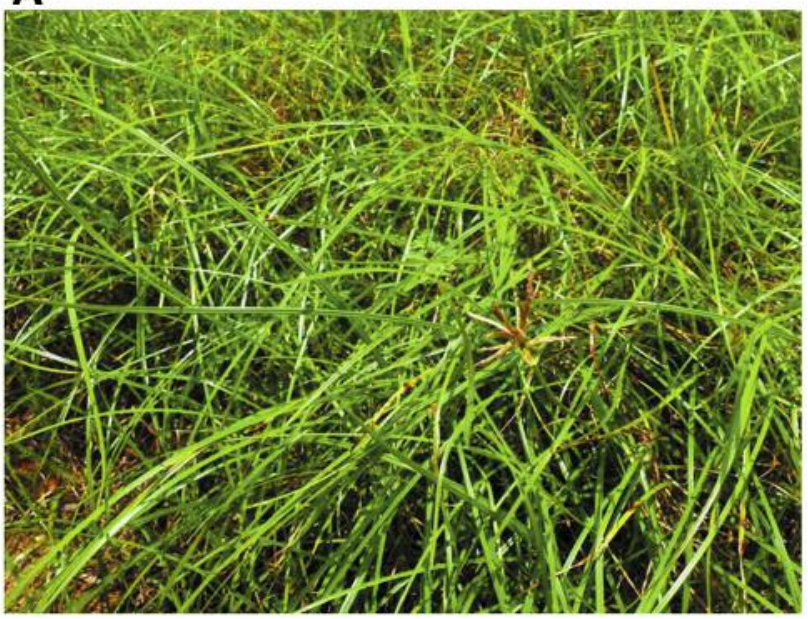

B

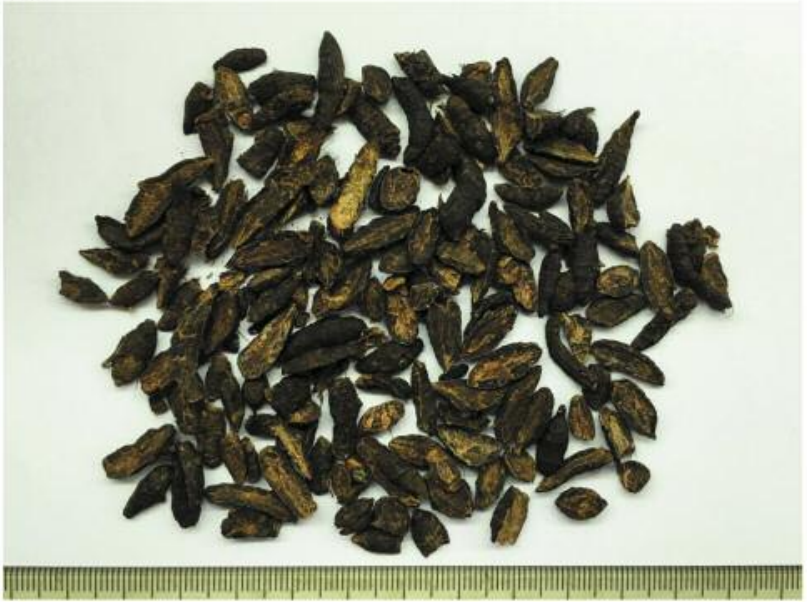

Figure 1. The wild plant (A) and the dried rhizome (B) of Cyperus rotundus.

inhibitory concentration $\left(\mathrm{IC}_{50}\right)$ for the 48 -h treatment of $\mathrm{CRE}$ in HeLa cells was $300 \mu \mathrm{g} / \mathrm{ml}$. Therefore, CRE at 300 $\mu \mathrm{g} / \mathrm{ml}$ was selected for the following steps of our study.

CRE induced chromatin condensations of HeLa cells by $D A P I$ staining. For further verifying whether CRE decreased the total number of viable HeLa cells through apoptosis, cells were incubated with different concentrations of CRE for 48 hours, and were stained by DAPI to assess the formation of chromatin condensation. As shown in Figure $3 \mathrm{~A}$ and B, the higher fluorescence intensity (DAPI staining) was the result of chromatin condensation (15) at much higher levels in CRE-treated HeLa cells compared to control. Similar to the effect of CRE in cell viability, the results from this experiment also indicated that $\mathrm{CRE}$-induced chromatin condensation occurred at a concentration-dependent manner.
CRE induces up-and down-regulation of gene expression in HeLa cells. The results from the cDNA microarray analysis, regarding apoptosis, are shown in Tables I and II. Quantification and data filtration revealed 33297 native features in our dataset; however, after collapsing features into gene symbols, only 20,693 features remained. The genes included in the CRE-treated group were 10,616 with a correlation area $53.5 \%$ while the control group was 10,077 with a correlation area $46.5 \%$. That indicates the gene expression in CRE-treated and control groups were different. Furthermore, the differences of gene expression between these two groups were compared in the HeLa cell. Table I shows 11 genes exhibiting $>10$-fold change and 8 genes with a $>5$-fold change. This list includes: i) DDIT3 and $G A D D 45 A$ that are genes associated with DNA damage (17), ii) $C D K N 1 A$ and $C D K N 2 B$ that are genes associated with the cell cycle $(18,19)$, iii) NCF2, ATP6VOD2, HMOX1, ATF3, and $C G R R F 1$ genes, related to cell survival $(20,21)$, and iv) TNFRSF 21, TRAF1, IL6, and ATG13 genes, related to cell apoptosis (22-24). Table II shows genes that were downregulated. This includes the DDIAS gene, linked to DNA damage (25), while some genes, such as $C D K 1, C C N F$, CDCA2, CCNA2, CDCA3, GTSE1, CCNE2, CDC20, and $C D K 2$, which are associated with cell cycle $(26,27)$.

Table III indicates the gene ontology categories of biological processes, cellular component, and molecular function. There are 125 genes related to cell cycle and 184 genes related to the function of an intracellular nonmembrane-bound organelle. Molecular function describes activities, such as catalytic reaction or binding that occurs at a molecular level. The nucleotide or nucleoside binding had the deepest impact on the gene expression of CRE-treated cells. According to the results of the BIOCARTA pathway analysis shown in Table IV, the differentially expressed genes in CRE-treated HeLa cells were related to cell cycle and cancer pathways.

The cDNA microarray analysis of CRE-treated or untreated cells revealed the results of top, second and third scores, as shown in Figures 4-6, respectively. The analysis results are mapped on the processes presenting possible signal effects. Genes marked red are upregulated while bluemarked genes are downregulated. Circles of different intensities display different enhancement or suppression of genes in CRE-treated HeLa cells compared to control cells. Especially, some genes show up- and down-regulation to associate with apoptosis of cancer cells. NFATC2 controls melanoma dedifferentiation by inducing expression in carcinoma cells of membrane-bound tumor necrosis factor$\alpha$ (mTNF- $\alpha)$, while melanoma-expressed TNF- $\alpha$ regulates a c-myc-Brn2 axis.(28). JOSD1 depletion can lead to severe apoptosis in gynaecological cancer cells both in vivo and in vitro (29). The PTGS2 gene, which encodes cyclooxygenase 2 (COX-2), is deregulated in endometriotic lesions and 
A

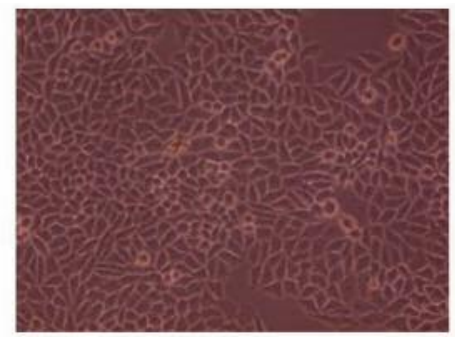

Control (200x)

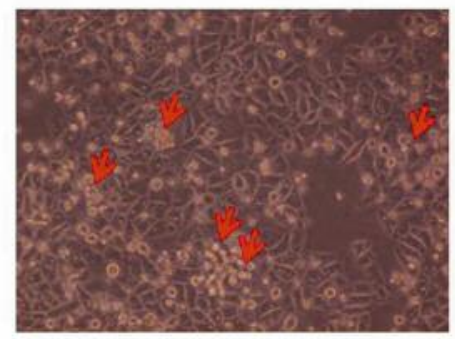

$300 \mu \mathrm{g} / \mathrm{ml}(200 \mathrm{x})$

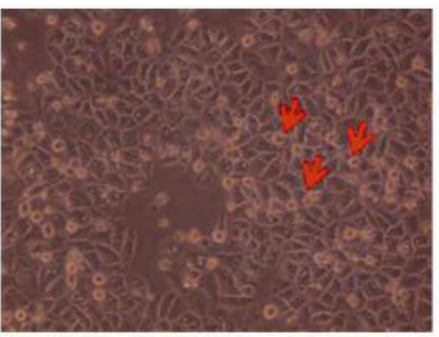

$100 \mu \mathrm{g} / \mathrm{ml}(200 \mathrm{x})$

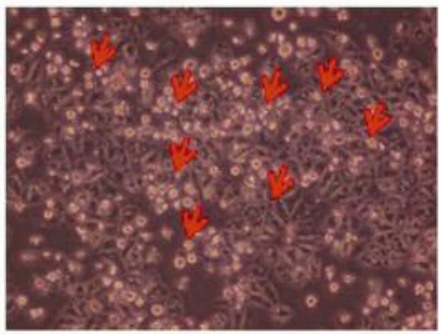

$400 \mu \mathrm{g} / \mathrm{ml}(200 \mathrm{x})$

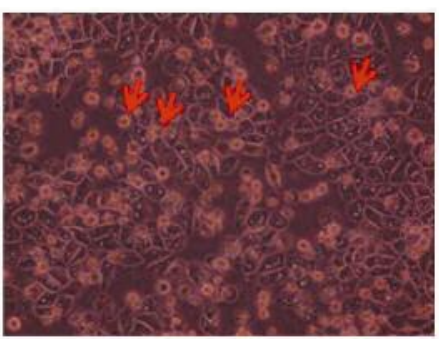

$200 \mu \mathrm{g} / \mathrm{ml}(200 \mathrm{x})$

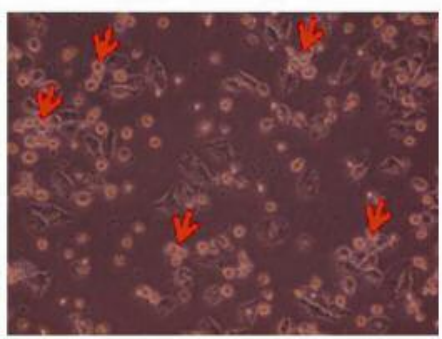

$500 \mu \mathrm{g} / \mathrm{ml}(200 \mathrm{x})$

B

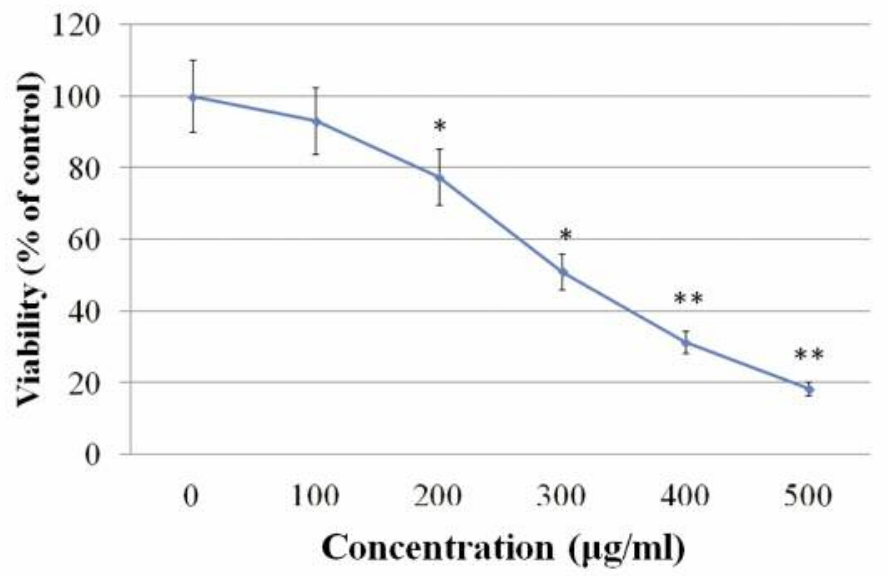

Figure 2. CRE induced cell morphological changes and decreased the total number of viable HeLa cells. Morphology changes of HeLa cells rounding up and condensing (red arrows) were observed and photographed under a phase contrast microscope at 200× magnification (A). All cells were stained by propidium iodide (PI) and the percentage of viable cells was calculated (B) following treatment with different concentrations of CRE $(100,200,300,400$, and $500 \mu \mathrm{g} / \mathrm{ml})$ for 48 hours.

plays an important role in the acquisition of oocyte competence (30). IRAK is responsible for the regulation of microbial colonization of tumors and STAT3 protein stability in tumor cells, leading to tumor cell proliferation (31). Ectopic expression of MDA-5 has been shown to induce carcinoma cell death, and then intentionally targeting the evolutionarily keep MDA-5-IPS-1 antiviral pathway in tumors can cause parallel tumoricidal effect that creates a bridge between innate and adaptive immune responses for the therapeutic treatment of cancer (32). These three maps show proteins and genes that are part of pro-apoptotic pathways in cancer cells.

\section{Discussion}

C. rotundus is used as a gynecological medicine in Chinese medicine. Many ancient books, such as Jingui Yaolue, Yizong Jinjian, Shanghan Lun, etc., have recorded a therapeutic formula containing $C$. rotundus (33). We attempted to provide some scientific explanations with regards to this traditional treatment. In this study, we evaluated the effects of CRE on apoptotic cell death and associated gene expression of HeLa human cervical cancer cells. CRE induced cell morphological changes and reduced the total number of viable cells in a dose-dependent manner. Following treatment with various doses of CRE, HeLa 
A

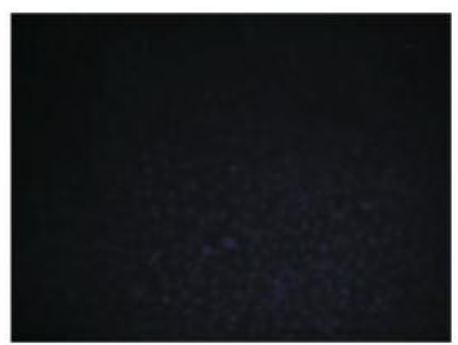

Control (200x)

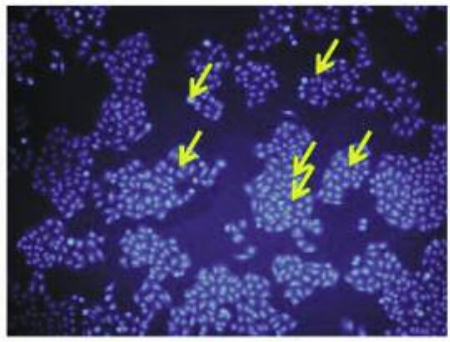

$300 \mu \mathrm{g} / \mathrm{ml}(200 \mathrm{x})$

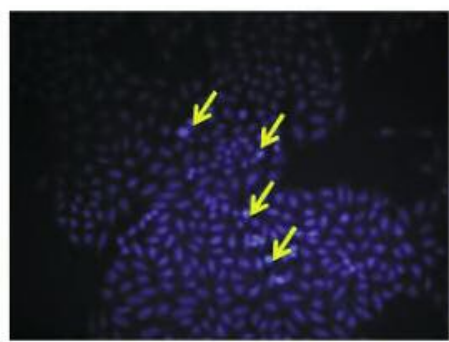

$100 \mu \mathrm{g} / \mathrm{ml}(200 \mathrm{x})$

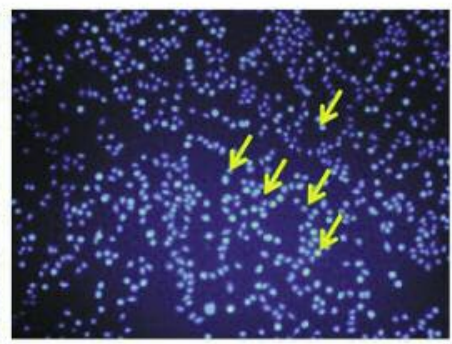

$400 \mu \mathrm{g} / \mathrm{ml}(200 \mathrm{x})$

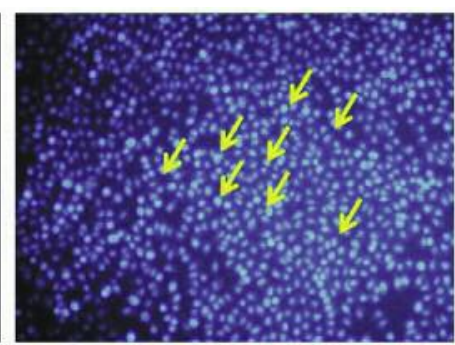

$200 \mu \mathrm{g} / \mathrm{ml}(200 \mathrm{x})$

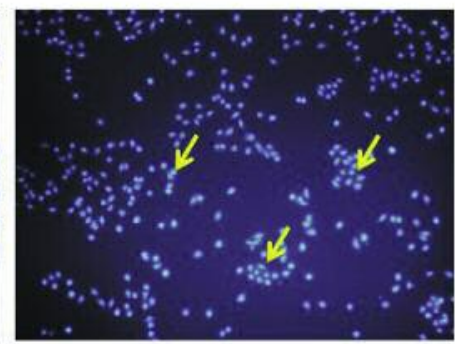

$500 \mu \mathrm{g} / \mathrm{ml}(200 \mathrm{x})$

B

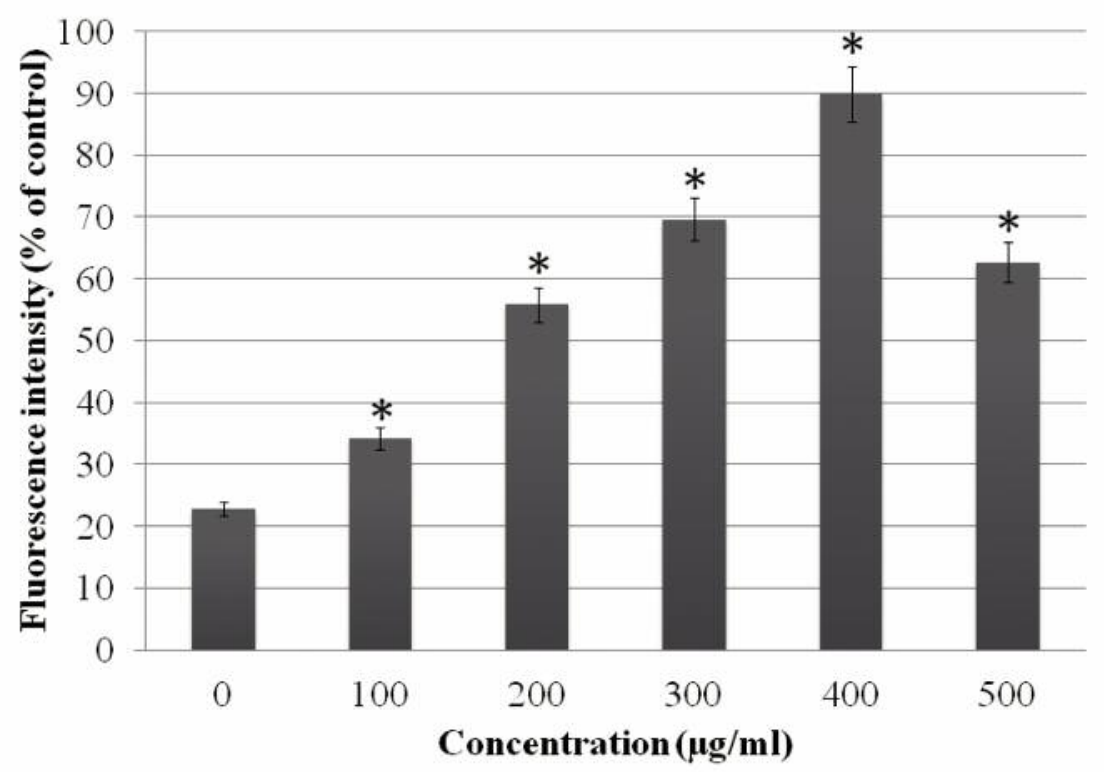

Figure 3. CRE-induced chromatin condensation in HeLa cells. The HeLa human cervical carcinoma cells were incubated with various concentrations of CRE (100, 200, 300, 400, and $500 \mu \mathrm{g} / \mathrm{ml})$ for 48 hours and chromatin condensation (apoptosis) was determined by DAPI staining (A, yellow arrows). The relative fluorescence intensity of $C R E$-treated cells was calculated $(B) .{ }^{*} p<0.05$ shows the significant difference between $C R E$-treated groups and the control, as analyzed by a Student t-test.

cells were characterized by chromatin condensation measured by DAPI staining. Chromatin condensation has been recognized to be a marker of cell death (34). To investigate whether CRE induced cytotoxic effects and cell death by regulating the expression of apoptosis-associated genes in HeLa cells, we used cDNA microarray assay.
CRE treatment promoted the expression of certain genes associated with DNA damage and cell growth arrest, such as DDIT3 and GADD 45A $(35,36)$. Also affected by CRE, the NCF2 gene, which encodes for the neutrophil cytosolic factor 2, is the $67-\mathrm{kDa}$ cytosolic subunit of the multi-protein NADPH oxidase complex and a novel p53-targeted gene 
Table I. Up-regulated genes expressions following CRE treatment of HeLa cells.

\begin{tabular}{|c|c|c|c|c|}
\hline Gene symbol & Gene description & Fold change & $p$-Value & $*$ FDR $p$-Value \\
\hline NCF2 & Neutrophil cytosolic factor 2 & 64.12 & 0.0005 & 0.0105 \\
\hline ATP6V0D2 & ATPase, $\mathrm{H}+$ transporting, lysosomal $38 \mathrm{kDa}, \mathrm{V} 0$ subunit $\mathrm{d} 2$ & 43.54 & 0.0001 & 0.0047 \\
\hline GDF15 & Growth differentiation factor 15 & 40.39 & $2.86 \times 10^{-8}$ & $5.84 \times 10^{-5}$ \\
\hline CCL5 & Chemokine (C-C motif) ligand 5 & 32.17 & 0.0471 & 0.1672 \\
\hline IFI44 & Interferon-induced protein 44 & 23.49 & 0.0006 & 0.0119 \\
\hline IFIT2 & Interferon-induced protein with tetratricopeptide repeats 2 & 22.23 & $1.82 \times 10^{-5}$ & 0.0017 \\
\hline HMOX1 & Heme Oxygenase 1 & 21.27 & 0.0005 & 0.0005 \\
\hline DDIT3 & DNA-damage-inducible transcript 3 & 17.22 & $2.00 \times 10^{-6}$ & 0.0005 \\
\hline DDX58 & DEAD (Asp-Glu-Ala-Asp) box polypeptide 58 & 14.92 & 0.0002 & 0.0057 \\
\hline RSAD2 & Radical S-adenosyl methionine domain containing 2 & 13.56 & 0.0005 & 0.0005 \\
\hline CDKN1A & Cyclin-dependent kinase inhibitor 1A (p21, Cip1) & 10.52 & $3.49 \times 10^{-6}$ & 0.0007 \\
\hline IFIT1 & Interferon-induced protein with tetratricopeptide repeats 1 & 8.57 & $6.13 \times 10^{-5}$ & 0.0032 \\
\hline GADD45A & Growth arrest and DNA-damage-inducible, alpha & 7.15 & $1.95 \times 10^{-5}$ & 0.0017 \\
\hline TNFRSF9 & Tumor necrosis factor receptor superfamily, member 9 & 6.79 & 0.0393 & 0.1474 \\
\hline \multirow[t]{2}{*}{ CYP1B1 } & Cytochrome P450, family 1 , cubfamily B, polypeptide 1 & $6 / 04$ & $8.13 \times 10^{-5}$ & 0.0038 \\
\hline & Intereron induced, with helicase $\mathrm{C}$ domain 1 & 5.89 & 0.0008 & 0.0139 \\
\hline CD48 & CD68 moleule & 5.41 & 0.0006 & 0.011 \\
\hline PDCD1LG2 & Programmed cell death 1 ligand 2 & 5.22 & 0.0006 & 0.0112 \\
\hline SOD2 & Superoxide dismutase 2 , mitochondrial & 5.14 & 0.0291 & 0.1212 \\
\hline MIR22HG & MIR22 host gene; microRNA 22 & 4.88 & 0.1573 & 0.1573 \\
\hline CASP4 & Caspase 4 & 4.72 & 0.1573 & 0.1573 \\
\hline IL24 & Interleukin 24 & 4.58 & $2.14 \times 10^{-5}$ & 0.0018 \\
\hline ANXA3 & Annexin A3 & 4.39 & $1.98 \times 10^{-6}$ & 0.0005 \\
\hline ATF3 & Activating transcription factor 3 & 4.15 & 0.0002 & 0.0062 \\
\hline CRLF2 & Cytokine receptor-like factor 2 & 3.92 & $3.98 \times 10^{-5}$ & 0.0056 \\
\hline ERRFI1 & ERBB receptor feedback inhibitor 1 & 3.65 & $1.24 \times 10^{-5}$ & 0.0014 \\
\hline CYP1A1 & Cytochrome P450, family 1 , subfamily A, polypeptide 1 & 3.55 & $2.32 \times 10^{-6}$ & 0.0023 \\
\hline CCPG1 & Cell cycle progression 1; DYX1C1-CCPG1 readthrough (NMD candidate) & 3.36 & $1.83 \times 10^{-6}$ & 0.0005 \\
\hline C6orf48 & Chromosome 6 open reading frame 48 & 3.32 & 0.0007 & 0.012 \\
\hline BCL2L1 & BCL2-like 1 & 3.24 & 0.0002 & 0.0065 \\
\hline CDKN2B & Cyclin-dependent kinase inhibitor 2B (p15, inhibits CDK4) & 3.21 & 0.0002 & 0.0069 \\
\hline TP53INP1 & Tumor protein p53 inducible nuclear protein 1 & 2.96 & 0.0002 & 0.0067 \\
\hline ID1 & Inhibitor of DNA binding 1, dominant negative helix-loop-helix protein & 2.84 & 0.0086 & 0.0554 \\
\hline TNFRSF10B & Tumor necrosis factor receptor superfamily, member $10 \mathrm{~b}$ & 2.73 & 0.0231 & 0.0231 \\
\hline CARD16 & Caspase recruitment domain family, member 16 ; caspase 1 & 2.71 & 0.0054 & 0.0076 \\
\hline HERPUD1 & $\begin{array}{l}\text { Homocysteine-inducible, endoplasmic reticulum stress-inducible, } \\
\text { ubiquitin-like domain member } 1\end{array}$ & 2.58 & 0.0044 & 0.0044 \\
\hline BTG1 & B-cell translocation gene 1, anti-proliferative & 2.56 & 0.0002 & 0.0019 \\
\hline RND1 & Rho family GTPase 1 & 2.54 & 0.0097 & 0.0597 \\
\hline IRAK2 & Interleukin 1 receptor associated kinase 2 & 2.49 & 0.0003 & 0.0086 \\
\hline MIR222 & microRNA 222 & 2.39 & 0.0004 & 0.0098 \\
\hline RRAGC & Ras-regulation GTP binding C & 2.33 & 0.0031 & 0.0294 \\
\hline TNFRSF2 1 & Tumor necrosis factor receptor superfamily, member 21 & 2.3 & 0.0045 & 0.0022 \\
\hline TRAF1 & TNF receptor-associated factor 1 & 2.24 & $2.98 \times 10^{-5}$ & 0.0034 \\
\hline IL7R & Interleukin 7 receptor & 2.21 & $1.86 \times 10^{-6}$ & 0.0005 \\
\hline CGRRF1 & Cell growth regulator with ring domain 1 & 2.2 & $3.76 \times 10^{-6}$ & 0.0006 \\
\hline C21orf91 & Chromosome 21 open reading frame 91 & 2.19 & 0.0014 & 0.0182 \\
\hline GRB10 & Growth factor receptor bound protein 10 & 2.13 & 0.002 & 0.0233 \\
\hline TNFAIP3 & Tumor necrosis factor, alpha-induced protein 3 & 2.09 & 0.0076 & 0.0511 \\
\hline IL6 & Interleukin 6 & 2.08 & $3.65 \times 10^{-5}$ & 0.0022 \\
\hline ATG13 & Autophagy related 13 & 2.07 & 0.0005 & 0.0108 \\
\hline GADD45B & Growth arrest and DNA-damage-inducible, beta & 2.03 & 0.0031 & 0.0294 \\
\hline
\end{tabular}

*FDR means false discovery rate.

(21). Reactive oxygen species (ROS) are a by-product of normal oxygen metabolism and play a large role in cell signaling, while maintaining body contingency. However, the amount of ROS can increase dramatically under the influence of time and stress from the external environment, for example, UV or heat exposure, and may have an important role in regulating signal transduction pathways (37). The cause of change in NCF2 expression may be due 
Table II. Down-regulation of gene expressions in CRE-treated HeLa cells.

\begin{tabular}{|c|c|c|c|c|}
\hline Gene symbol & Gene description & Fold change & $p$-Value & *FDR $p$-Value \\
\hline MGP & Matrix Gla protein & -14.14 & 0.0035 & 0.0316 \\
\hline HPD & 4-Hydroxyphenylpyruvate dioxygenase & -9.65 & 0.0006 & 0.0113 \\
\hline CACNB2 & Calcium channel, voltage-dependent, beta 2 subunit & -9.18 & $5.37 \times 10^{-5}$ & 0.003 \\
\hline LINC00052 & Long intergenic non-protein coding RNA 52 & -8.98 & $4.35 \times 10^{-5}$ & 0.0028 \\
\hline KIAA0825 & KIAA0825 & -8.11 & 0.0006 & 0.0111 \\
\hline HIST1H1B & Histone cluster $1, \mathrm{H} 1 \mathrm{~b}$ & -8.02 & 0.0171 & 0.086 \\
\hline FAM111B & Family with sequence similarity 111 , member B & -7.65 & 0.0008 & 0.0132 \\
\hline CPA4 & Carboxypeptidase A4 & -7.61 & $8.80 \times 10^{-7}$ & 0.0004 \\
\hline SLF1 & SMC5-SMC6 complex localization factor 1 & -7.18 & 0.0002 & 0.0067 \\
\hline SLC12A3 & Solute carrier family 12 (sodium/chloride transporter), member 3 & -6.53 & 0.0084 & 0.0544 \\
\hline CDK1 & Cyclin-dependent kinase 1 & -4.63 & 0.0145 & 0.0774 \\
\hline MKI67 & Ki-67 (marker of proliferation) & -4.22 & 0.0032 & 0.0302 \\
\hline CASC5 & Cancer susceptibility candidate 5 & -4.17 & 0.0002 & 0.0058 \\
\hline $\mathrm{CD} 24$ & $\mathrm{CD} 24$ molecule & -3.57 & $6.94 \times 10^{-5}$ & 0.0034 \\
\hline $\mathrm{CCNF}$ & Cyclin F & -3.42 & 0.0004 & 0.0091 \\
\hline $\mathrm{CDCA} 2$ & Cell division cycle associated 2 & -3.29 & 0.0008 & 0.0131 \\
\hline CCNA2 & Cyclin A2 & -3.25 & $2.27 \times 10^{-5}$ & 0.0019 \\
\hline CDCA3 & Cell division cycle associated 3 & -3.24 & 0.0081 & 0.0534 \\
\hline POLQ & Polymerase (DNA directed), theta & -3.2 & 0.0029 & 0.0283 \\
\hline MITF & Microphthalmia-associated transcription factor & -3.19 & 0.0005 & 0.0109 \\
\hline CCNB1 & Cyclin B1 & -3.17 & 0.0073 & 0.0498 \\
\hline GTSE1 & $\begin{array}{l}\text { G2 and S phase expressed 1; tRNA 5-methylaminomethyl- } \\
\text { 2-thiouridylate methyltransferase }\end{array}$ & -3.06 & 0.0022 & 0.024 \\
\hline CDC45 & Cell division cycle 45 & -2.99 & 0.0063 & 0.0453 \\
\hline MARC1 & Mitochondrial amidoxime reducing component 1 & -2.91 & 0.0014 & 0.0182 \\
\hline HIST1H2AJ & Histone cluster 1, H2aj & -2.85 & 0.0021 & 0.0238 \\
\hline HIST1H2AB & Histone cluster $1, \mathrm{H} 2 \mathrm{ab}$ & -2.8 & $3.06 \times 10^{-5}$ & 0.0023 \\
\hline CCNE2 & Cyclin E2 & -2.74 & 0.0009 & 0.0145 \\
\hline HIST1H3D & Histone cluster $1, \mathrm{H} 3 \mathrm{~d}$; Histone cluster $1, \mathrm{H} 2 \mathrm{ad}$ & -2.66 & 0.0003 & 0.0072 \\
\hline DNA2 & DNA replication helicase/nuclease 2 & -2.59 & $1.14 \times 10^{-5}$ & 0.0013 \\
\hline CDCA8 & Cell division cycle associated 8 & -2.52 & 0.0063 & 0.0452 \\
\hline CDC25A & Cell division cycle associated 5 & -2.47 & $3.78 \times 10^{-5}$ & 0.0025 \\
\hline PCNA & Proliferating cell nuclear antigen & -2.4 & 0.0011 & 0.0163 \\
\hline CRACR2A & Calcium release activated channel regulator $2 \mathrm{~A}$ & -2.31 & $4.16 \times 10^{-6}$ & 0.0008 \\
\hline MPHOSPH9 & M-phase phosphoprotein 9 & -2.28 & $4.47 \times 10^{-5}$ & 0.0028 \\
\hline $\mathrm{CDC} 20$ & Cell division cycle 20 & -2.28 & 0.0272 & 0.1158 \\
\hline DDIAS & DNA damage-induced apoptosis suppressor & -2.24 & $2.31 \times 10^{-5}$ & 0.0019 \\
\hline RERG & RAS-like, estrogen-regulated, growth inhibitor & -2.22 & 0.0389 & 0.2545 \\
\hline SKP2 & S-phase kinase-associated protein 2, E3 ubiquitin protein ligase & -2.15 & 0.0002 & 0.0069 \\
\hline BAG1 & BCL2-associated athanogene & -2.14 & 0.0045 & 0.0388 \\
\hline MTFR2 & Mitochondrial fission regulator 2 & -2.13 & 0.0004 & 0.0078 \\
\hline CDK2 & Cyclin-dependent kinase 2 & -2.11 & 0.0308 & 0.1259 \\
\hline WEE1 & WEE1 G2 checkpoint kinase & -2.08 & 0.0005 & 0.0107 \\
\hline ATP5EP2 & ATP synthase, $\mathrm{H}+$ transporting, mitochondrial F1 complex & -2.06 & 0.0005 & 0.0208 \\
\hline IL17RB & Interleukin 17 receptor B & -2.05 & 0.0035 & 0.0467 \\
\hline HIST1H2AE & Histone cluster $1, \mathrm{H} 2 \mathrm{ae}$ & -2.05 & 0.0056 & 0.0670 \\
\hline CDKN3 & Cyclin-dependent kinase inhibitor 3 & -2.04 & 0.0002 & 0.0065 \\
\hline TGFB3 & Transforming growth factor beta 3 & -2.04 & 0.0045 & 0.0369 \\
\hline
\end{tabular}

*FDR means false discovery rate.

to significant damage caused to a cellular structure. p53 and its family members could act as upstream regulators of ROS by transcriptionally modulating genes related to cellular redox state and leading to cell death $(38,39)$. The expression of the NCF2 gene represents the highest fold change following CRE treatment of HeLa cells. Additional
ROS-related genes, such as SOD2 and TP53INP1, were also up-regulated in this study.

Importantly, CRE treatment induced cell-cycle arrest in HeLa cells. CRE-treated HeLa cell increased $p 21$ and $p 15$ expression by a 10.52- and 3.21-fold, respectively. These two cyclin-dependent kinase inhibitors (CDKIs), p21 and p15, 
Table III. Gene ontology categories of biological processes, cellular component and molecular function.

\begin{tabular}{lrrl}
\hline Gene ontology categories & $\begin{array}{r}\text { Total } \\
\text { genes }\end{array}$ & $\%$ & $p$-Value \\
& & & \\
\hline Biological process & & & \\
Cell cycle phase & 94 & 10.59 & $1.42 \times 10^{-38}$ \\
M phase & 84 & 9.47 & $1.99 \times 10^{-38}$ \\
M phase of mitotic cell cycle & 68 & 7.66 & $4.53 \times 10^{-36}$ \\
Mitosis & 67 & 7.55 & $1.25 \times 10^{-35}$ \\
Nuclear division & 67 & 7.55 & $1.25 \times 10^{-35}$ \\
Cell cycle & 125 & 14.09 & $1.94 \times 10^{-35}$ \\
Organelle fission & 68 & 7.66 & $2.09 \times 10^{-35}$ \\
Cell cycle process & 105 & 11.83 & $5.17 \times 10^{-35}$ \\
Mitotic cell cycle & 82 & 9.24 & $9.81 \times 10^{-33}$ \\
Cell division & 63 & 7.10 & $3.55 \times 10^{-24}$ \\
Cellular component & & & \\
Chromosomal part & 69 & 7.77 & $1.58 \times 10^{-23}$ \\
Chromosome & 75 & 8.45 & $4.55 \times 10^{-23}$ \\
Spindle & 41 & 4.62 & $2.63 \times 10^{-21}$ \\
Condensed chromosome & 38 & 4.28 & $1.17 \times 10^{-20}$ \\
Chromosome, centromeric region & 34 & 3.83 & $1.79 \times 10^{-17}$ \\
Condensed chromosome, & & & \\
centromeric region & 24 & 2.70 & $2.40 \times 10^{-15}$ \\
Microtubule cytoskeleton & 67 & 7.55 & $5.56 \times 10^{-14}$ \\
Condensed chromosome kinetochore & 21 & 2.36 & $2.02 \times 10^{-13}$ \\
Intracellular non-membrane- & & & \\
bounded organelle & 184 & 20.74 & $2.06 \times 10^{-12}$ \\
Non-membrane-bounded organelle & 184 & 20.74 & $2.06 \times 10^{-12}$ \\
Microtubule cytoskeleton & 67 & 7.55 & $5.56 \times 10^{-14}$ \\
Molecular function & & & \\
ATP binding & 102 & 11.49 & $1.12 \times 10^{-5}$ \\
Nucleoside binding & 109 & 12.28 & $1.30 \times 10^{-5}$ \\
Purine nucleoside binding & 108 & 12.17 & $1.57 \times 10^{-5}$ \\
Adenyl ribonucleotide binding & 102 & 11.49 & $1.96 \times 10^{-5}$ \\
Adenyl nucleotide binding & 106 & 11.95 & $2.26 \times 10^{-5}$ \\
Microtubule motor activity & 13 & 1.46 & $1.62 \times 10^{-4}$ \\
Ribonucleotide binding & 115 & 12.96 & $1.92 \times 10^{-4}$ \\
Purine ribonucleotide binding & 115 & 12.96 & $1.92 \times 10^{-4}$ \\
Purine nucleotide binding & 119 & 13.41 & $2.07 \times 10^{-4}$ \\
Nucleotide binding & 15.21 & $2.71 \times 10^{-4}$ \\
\hline & & \\
\hline
\end{tabular}

are proteins that bind to and inhibit the activity of CDKs and resulted in suppressed cell growth $(40,41)$.

Interestingly, two microRNA molecules, MIR22HG and MIR222, were up-regulated by 4.88- and 2.39-fold, respectively. Non-coding RNAs (lncRNAs and microRNAs) are non-protein-coding transcripts involved in various biological functions (42). MIR22HG, the host gene for miR22 , has been shown to be upregulated in response to chemical stresses or hypoxia (43-45). The other microRNA, miR-222, plays multiple roles in promoting cell proliferation, invasion, migration, and decreases cell apoptosis, while enhancing the sorafenib resistance of $\mathrm{HCC}$ cells by activating the PI3K/AKT signaling pathway (46). In addition, the literature has reported that $\mathrm{miR}-221 / \mathrm{miR}-222$ expression can also regulate post-
Table IV. BIOCARTA pathway analysis of the differentially expressed genes in CRE-treated HeLa cells.

\begin{tabular}{lcl}
\hline Term & Count & $p$-Value \\
\hline G1/S cell cycle check point & 7 & 0.014 \\
G2/M cell cycle check point & 6 & 0.02 \\
p53 signaling pathway & 5 & 0.028 \\
Role of Ran in mitotic spindle regulation & 4 & 0.048 \\
ATM signaling pathway & 5 & 0.049 \\
Low-Density Lipoprotein (LDL) & & \\
pathway during atherogenesis & 3 & 0.063 \\
Caspase cascade in apoptosis & 5 & 0.087 \\
Cyclins and cell cycle regulation & 5 & 0.098 \\
Cell cycle & 28 & $2.75 \times 10^{-10}$ \\
p53 signaling pathway & 16 & $2.24 \times 10^{-6}$ \\
Oocyte meiosis & 17 & $2.40 \times 10^{-4}$ \\
DNA replication & 8 & 0.002 \\
Pyrimidine metabolism & 13 & 0.004 \\
Lysosome & 14 & 0.009 \\
Systemic lupus erythematosus & 12 & 0.017 \\
Pathways in cancer & 28 & 0.017 \\
Tryptophan metabolism & 7 & 0.019 \\
\hline
\end{tabular}

transcriptionally the expression of $\mathrm{p} 27^{\mathrm{Kip} 1}$ and affect the proliferation of cancer cells $(47,48)$. Despite this data, the molecular mechanism of miR-222 concerning CRE treatment of HeLa cells is waiting for further clarification in the future.

Treatment with CRE also inhibited ertain gene expression profiles, such as cell cycle-associated genes CDK1 (cyclindependent kinase 1), WEE1 (WEE1 $\mathrm{G}_{2}$ checkpoint kinase), and CDC25A (cell division cycle associated 5). There are literature reports showing poor prognosis for gastric cancer patients with overexpressed carboxypeptidase A4 (CPA4), a zinc-containing exopeptidase (49). In this study, elevated CPA4 expression was detected in more than $50 \%$ of primary gastric cancer cases but it was weak or absent from the normal mucosa. Clinical relevance analysis has shown that CPA4 is significantly associated with tumor growth, stage, lymph node metastasis, invasion and distal metastasis. In another study, CPA4 was associated with prostate cancer aggressiveness, histone hyperacetylation pathway, and possibly the modulation of growth-affected peptides' function and the regulation of prostate epithelial cells (50). Our results showed that CRE-treated HeLa cells decreased CPA4 gene expression by 7.61-fold, which we believe provide the first report concerning the expression of CPA4 in HeLa cells.

Gene expression changes in CRE-treated HeLa cells were classified into: i) biological processes, ii) cellular components, and iii) molecular functions. Results showed that cell cycle and related processes, intracellular non-membrane-bounded organelles, and nucleoside-binding genes were associated with the CRE treatment in HeLa cells. Furthermore, the 


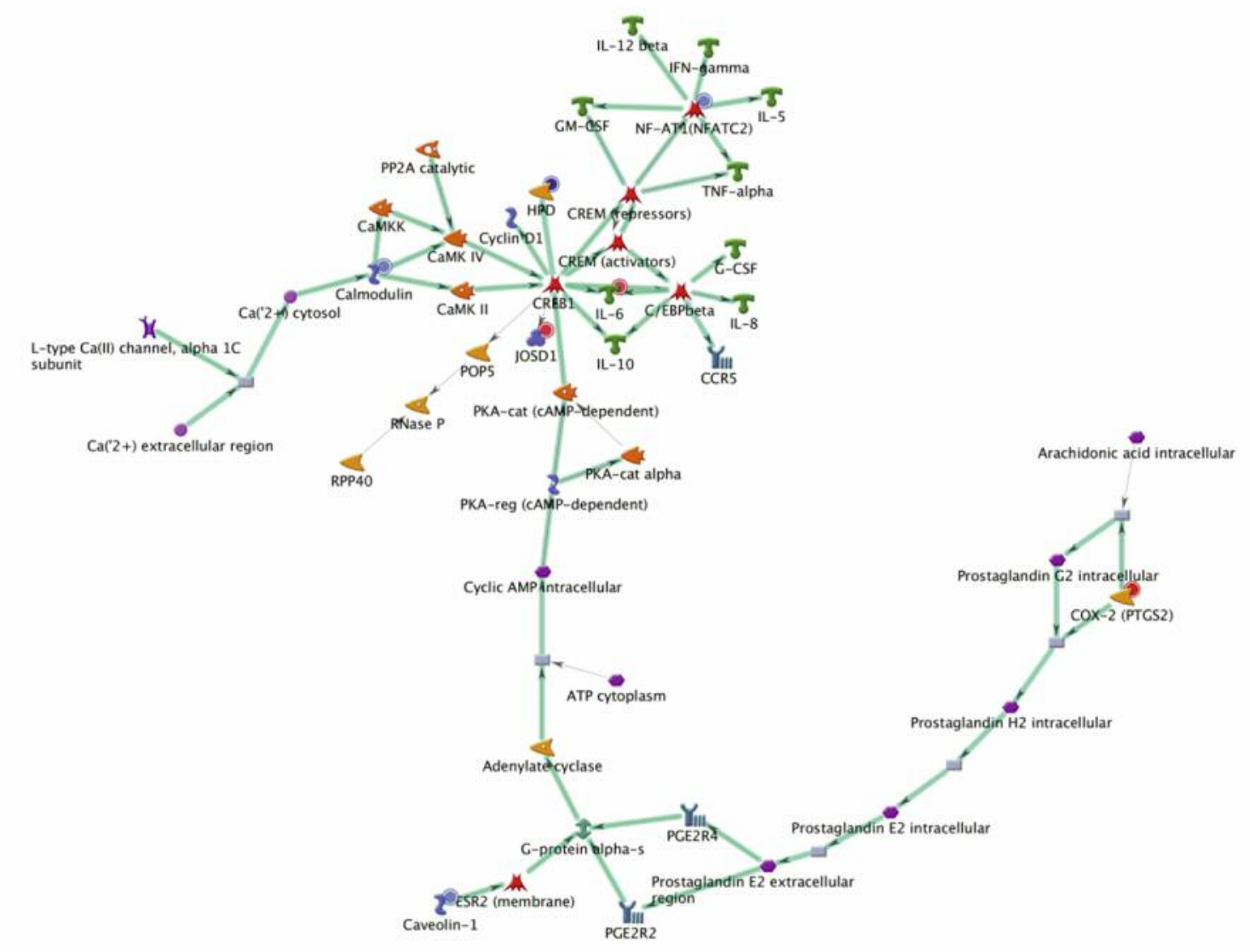

\begin{tabular}{|c|c|c|c|c|c|c|c|c|c|c|c|}
\hline$\checkmark$ & $\begin{array}{l}\text { Generic } \\
\text { enzyme }\end{array}$ & $\Delta$ & $\begin{array}{l}\text { Generic } \\
\text { phosphatase }\end{array}$ & 75 & Recepplor ligand & Fै & $\begin{array}{l}\text { Cell mentrane } \\
\text { glycoporokin }\end{array}$ & $\&$ & $\begin{array}{l}\text { Generic } \\
\text { phaspholipuse }\end{array}$ & 4 & Li.pid kinase \\
\hline $\mathbb{s}$ & $\begin{array}{l}\text { Generic } \\
\text { kinse }\end{array}$ & $\alpha$ & $\begin{array}{l}\text { Protein } \\
\text { phosphatsese }\end{array}$ & 1 & Trasseription fictor & 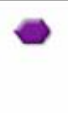 & Compound & 2 & $\begin{array}{l}\text { Generic binding } \\
\text { provein }\end{array}$ & 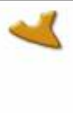 & Generie protense \\
\hline \& & $\begin{array}{l}\text { Protein } \\
\text { kimase }\end{array}$ & $\alpha$ & $\begin{array}{l}\text { Lipid } \\
\text { phosphatsese }\end{array}$ & & Provein & & $\begin{array}{l}\text { Presicted } \\
\text { metublitic or } \\
\text { wser's structure }\end{array}$ & & Generic respostor & $<$ & Meatloprocease \\
\hline
\end{tabular}

Figure 4. The top scored network from CRE IC50 and control samples. Thick cyan lines indicate the fragments of canonical pathways. Up-regulated genes are marked with red circles; down-regulated with blue circles.

BIOCARTA pathway analysis indicated that CRE treatment affected the $G_{1} / S$ and $G_{2} / M$ cell-cycle check point, p53 and ATM signaling pathways, as well as the caspase cascade in HeLa cells.

In summary, CRE decreased HeLa cell viability and induced chromatin condensation. The affected gene expression in CRE-treated HeLa cells were analyzed using cDNA microarray analysis, which provided complete information on the genes and pathways targeted by CRE in HeLa cells following $48 \mathrm{~h}$ of treatment. From these observations, we have illustrated the possible signal transduction pathways involved with the affected genes following CRE-treatment. Future investigations are needed to extend our new findings and obtain experimental evidence concerning the molecular mechanism of the identified targets following CRE treatment in cervical cancer.

\section{Conflicts of Interest}

The Authors confirm that there are no conflicts of interest. 


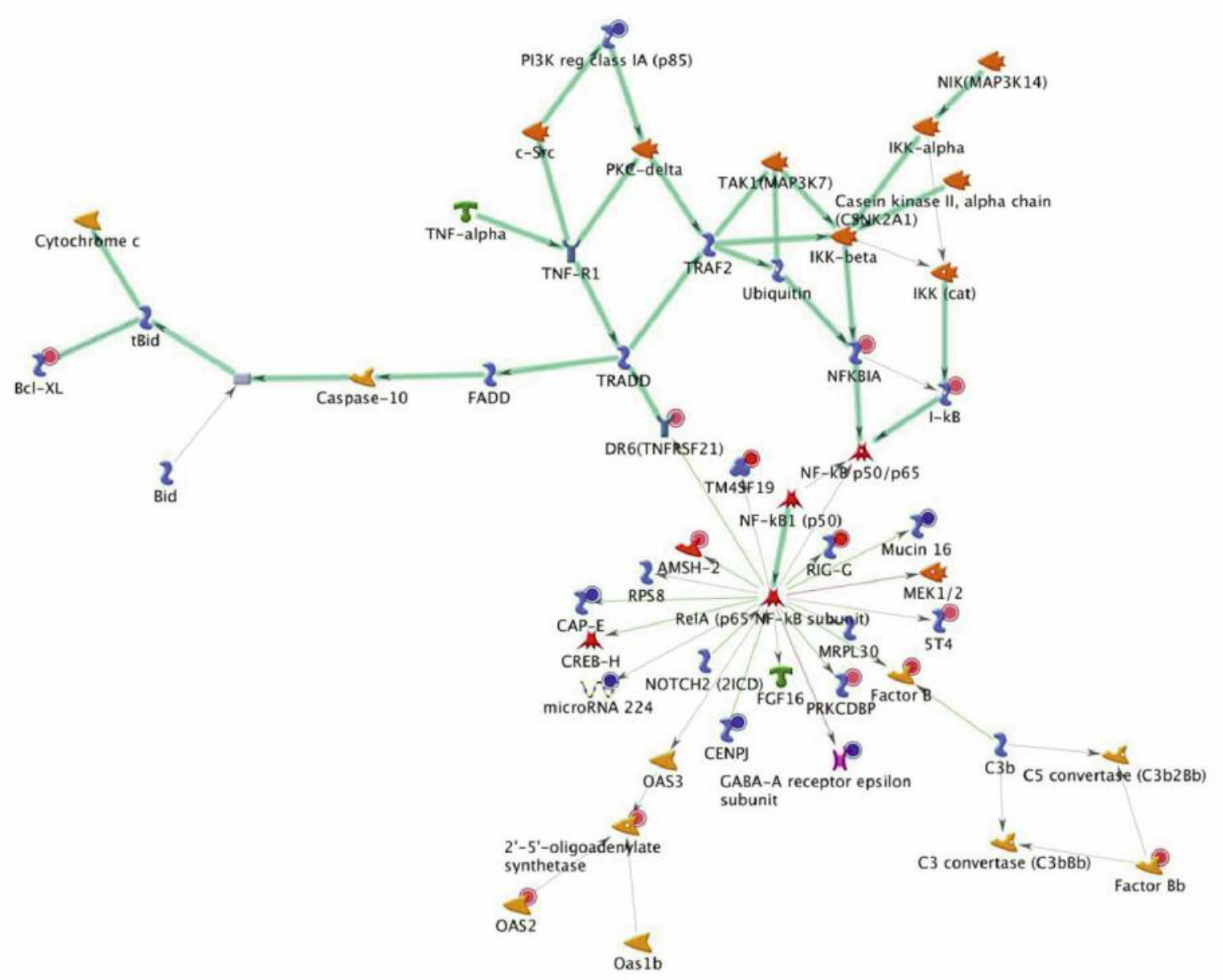

\begin{tabular}{|c|c|c|c|c|c|c|c|c|c|c|c|}
\hline$<$ & $\begin{array}{l}\text { Generic } \\
\text { enzyme }\end{array}$ & 0 & $\begin{array}{l}\text { Generic } \\
\text { plimsphatase }\end{array}$ & 5 & Receppor ligend & $\frac{k}{F}$ & $\begin{array}{l}\text { Cell mentrase } \\
\text { efysoppotion }\end{array}$ & $\Leftrightarrow$ & $\begin{array}{l}\text { Generic } \\
\text { phosppolipase }\end{array}$ & $<$ & Lipid kinse \\
\hline 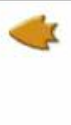 & $\begin{array}{l}\text { Generic } \\
\text { kimse }\end{array}$ & $\alpha$ & $\begin{array}{l}\text { Procin } \\
\text { phosphatase }\end{array}$ & M & Tresescriplina factar & 0 & Compouma & 2 & $\begin{array}{l}\text { Generic binding } \\
\text { protinin }\end{array}$ & 3 & Geseric potanese \\
\hline 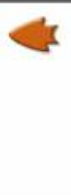 & $\begin{array}{l}\text { Provein } \\
\text { kinse }\end{array}$ & $\alpha$ & $\begin{array}{l}\text { Lipia } \\
\text { phopophatase }\end{array}$ & 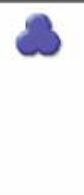 & Protetin & D & $\begin{array}{l}\text { Predicied } \\
\text { metabolite or } \\
\text { usser's structure }\end{array}$ & $\mathbf{Y}$ & Genertic reveptor & -3 & Mealloportasese \\
\hline
\end{tabular}

Figure 5. The second scored network from CRE IC 50 and control sample. Thick cyan lines indicate the fragments of canonical pathways. Up-regulated genes are marked with red circles; down-regulated with blue circles.

\section{Authors' Contributions}

CHL, CLK and JGC conceived and designed the experiments. CHL and SFP performed the experiments. CHL, ZYC and SFP analyzed the data. CLK and JGC contributed towards reagents/materials/ analysis tools. CHL, SFP and JGC wrote the paper.

\section{Acknowledgements}

Experiments and data analysis were performed in part through the use of the Medical Research Core Facilities Center, Office of Research \& Development at China Medical University, Taichung, Taiwan, R.O.C. 


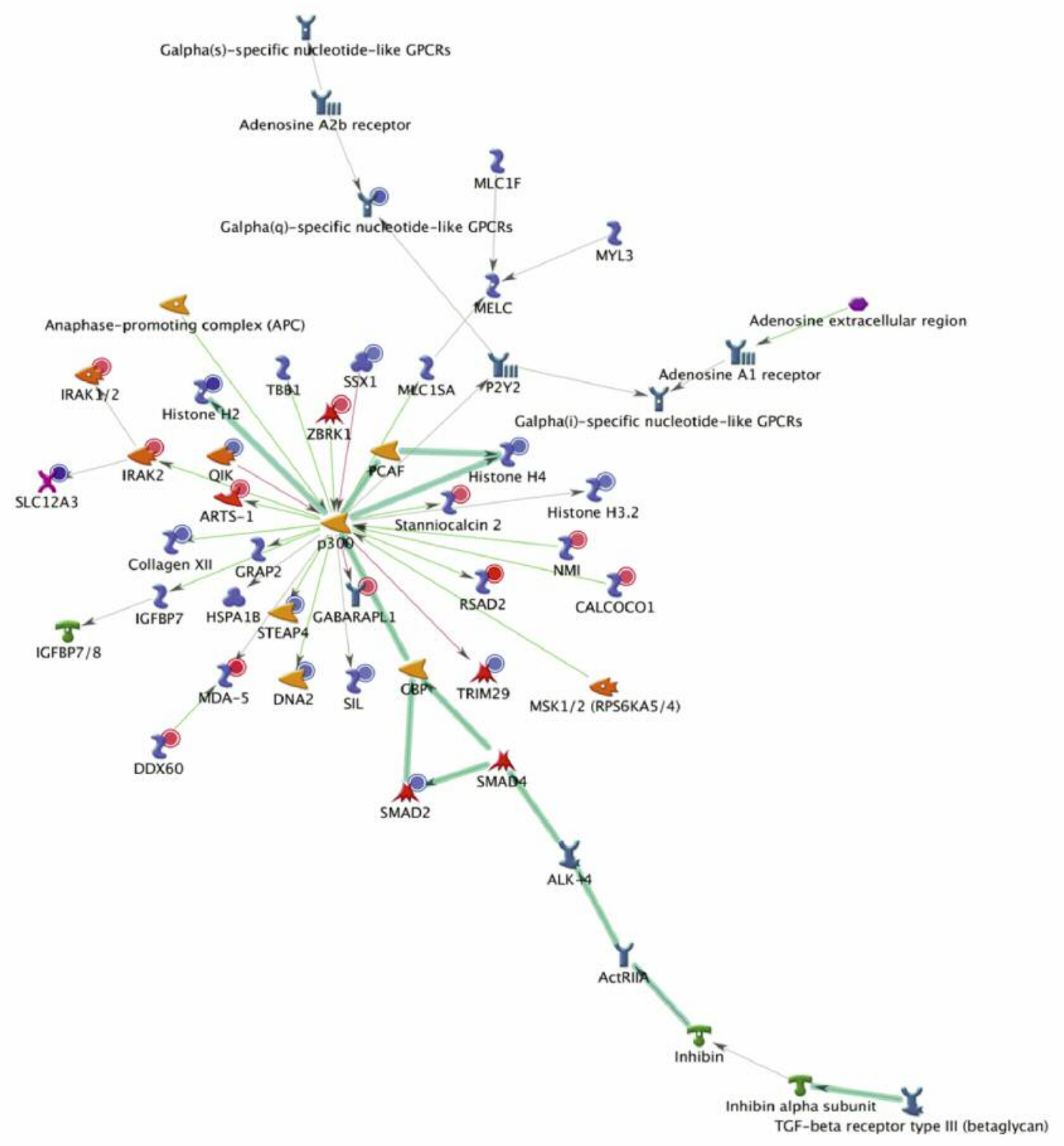

\begin{tabular}{|c|c|c|c|c|c|c|c|c|c|c|c|}
\hline 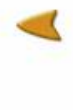 & $\begin{array}{l}\text { Generic } \\
\text { enzyme }\end{array}$ & d & $\begin{array}{l}\text { Generic } \\
\text { plosphatiase }\end{array}$ & 75 & Recepter ligand & $\frac{F}{F}$ & $\begin{array}{l}\text { Cell membrane } \\
\text { gybroportein }\end{array}$ & $\Leftrightarrow$ & $\begin{array}{l}\text { Generic } \\
\text { phospholipase }\end{array}$ & $<$ & Lipid kinase \\
\hline & $\begin{array}{l}\text { Genertic } \\
\text { kinase }\end{array}$ & 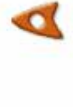 & $\begin{array}{l}\text { Prottin } \\
\text { phosphatise }\end{array}$ & & Transeription faceor & & Compound & 2 & $\begin{array}{l}\text { Generic binding } \\
\text { pootein }\end{array}$ & 3 & Generic protesse \\
\hline 3 & $\begin{array}{l}\text { Protin } \\
\text { kinase }\end{array}$ & $\alpha$ & $\begin{array}{l}\text { Lipid } \\
\text { ploosphatase }\end{array}$ & & Protin & & $\begin{array}{l}\text { Predicted } \\
\text { metabolite of } \\
\text { user's structure }\end{array}$ & $Y$ & Generic reseptior & $<$ & Metalloprovesese \\
\hline
\end{tabular}

Figure 6. The third scored network from CRE IC 50 and control sample. Thick cyan lines indicate the fragments of canonical pathways. Up-regulated genes are marked with red circles; down-regulated with blue circles. 


\section{References}

1 Chen HY, Huang BS, Lin YH, Su IH, Yang SH, Chen JL, Huang JW and Chen YC: Identifying chinese herbal medicine for premenstrual syndrome: Implications from a nationwide database. BMC Complement Altern Med 14: 206, 2014. PMID: 24969368. DOI: $10.1186 / 1472-6882-14-206$

2 Pirzada AM, Ali HH, Naeem M, Latif M, Bukhari AH and Tanveer A: Cyperus rotundus 1.: Traditional uses, phytochemistry, and pharmacological activities. J Ethnopharmacol 174: 540-560, 2015. PMID: 26297840. DOI: 10.1016 /j.jep.2015.08.012

3 Gupta MB, Palit TK, Singh N and Bhargava KP: Pharmacological studies to isolate the active constituents from cyperus rotundus possessing anti-inflammatory, anti-pyretic and analgesic activities. Indian J Med Res 59(1): 76-82, 1971. PMID: 5574385.

4 Kilani S, Ben Sghaier M, Limem I, Bouhlel I, Boubaker J, Bhouri W, Skandrani I, Neffatti A, Ben Ammar R, DijouxFranca MG, Ghedira $\mathrm{K}$ and Chekir-Ghedira $\mathrm{L}$ : In vitro evaluation of antibacterial, antioxidant, cytotoxic and apoptotic activities of the tubers infusion and extracts of cyperus rotundus. Bioresour Technol 99(18): 9004-9008, 2008. PMID: 18538563. DOI: $10.1016 /$ j.biortech.2008.04.066

5 Sayed HM, Mohamed MH, Farag SF, Mohamed GA and Proksch P: A new steroid glycoside and furochromones from cyperus rotundus 1. Nat Prod Res 21(4): 343-350, 2007. PMID: 17479423. DOI: $10.1080 / 14786410701193056$

6 Hemanth Kumar K, Tamatam A, Pal A and Khanum F: Neuroprotective effects of cyperus rotundus on sin-1 induced nitric oxide generation and protein nitration: Ameliorative effect against apoptosis mediated neuronal cell damage. Neurotoxicology 34: 150-159, 2013. PMID: 23174672. DOI: 10.1016/j.neuro.2012.11.002

$7 \mathrm{Hu}$ QP, Cao XM, Hao DL and Zhang LL: Chemical composition, antioxidant, DNA damage protective, cytotoxic and antibacterial activities of cyperus rotundus rhizomes essential oil against foodborne pathogens. Sci Rep 7: 45231, 2017. PMID: 28338066. DOI: $10.1038 /$ srep45231

8 Kilani-Jaziri S, Neffati A, Limem I, Boubaker J, Skandrani I, Sghair MB, Bouhlel I, Bhouri W, Mariotte AM, Ghedira K, Dijoux Franca MG and Chekir-Ghedira L: Relationship correlation of antioxidant and antiproliferative capacity of cyperus rotundus products towards k562 erythroleukemia cells. Chem Biol Interact 181(1): 85-94, 2009. PMID: 19446539. DOI: 10.1016/j.cbi.2009.04.014

9 Uddin SJ, Mondal K, Shilpi JA and Rahman MT: Antidiarrhoeal activity of cyperus rotundus. Fitoterapia 77(2): 134-136, 2006. PMID: 16376024. DOI: 10.1016/j.fitote.2004.11.011

10 Naga Ch P, Gurram L, Chopra S and Mahantshetty U: The management of locally advanced cervical cancer. Curr Opin Oncol 30(5): 323-329, 2018. PMID: 29994902. DOI: 10.1097/ cco.0000000000000471

11 Ricci MS and Zong WX: Chemotherapeutic approaches for targeting cell death pathways. Oncologist 11(4): 342-357, 2006. PMID: 16614230. DOI: 10.1634/theoncologist.11-4-342

12 Hsieh WT, Lin HY, Chen JH, Lin WC, Kuo YH, Wood WG, Lu HF and Chung JG: Latex of euphorbia antiquorum-induced sphase arrest via active atm kinase and mapk pathways in human cervical cancer hela cells. Environ Toxicol 30(10): 1205-1215, 2015. PMID: 24706497. DOI:10.1002/tox.21992
13 Liu KC, Huang YT, Wu PP, Ji BC, Yang JS, Yang JL, Chiu TH, Chueh FS and Chung JG: The roles of aif and endo $g$ in the apoptotic effects of benzyl isothiocyanate on du 145 human prostate cancer cells via the mitochondrial signaling pathway. Int J Oncol 38(3): 787-796, 2011. PMID: 21206973. DOI: 10.3892/ ijo. 2010.894

14 Lee HZ, Liu WZ, Hsieh WT, Tang FY, Chung JG and Leung HW: Oxidative stress involvement in physalis angulata-induced apoptosis in human oral cancer cells. Food Chem Toxicol 47(3): 561-570, 2009. PMID: 19138722. DOI: 10.1016/j.fct.2008. 12.013

15 Chiang IT, Wang WS, Liu HC, Yang ST, Tang NY and Chung JG: Curcumin alters gene expression-associated DNA damage, cell cycle, cell survival and cell migration and invasion in ncih460 human lung cancer cells in vitro. Oncol Rep 34(4): 18531874, 2015. PMID: 26238775. DOI: 10.3892/or.2015.4159

16 Chen PY, Lin KC, Lin JP, Tang NY, Yang JS, Lu KW and Chung JG: Phenethyl isothiocyanate (peitc) inhibits the growth of human oral squamous carcinoma hsc-3 cells through $\mathrm{g}(0) / \mathrm{g}(1)$ phase arrest and mitochondria-mediated apoptotic cell death. Evid Based Complement Alternat Med 2012: 718320, 2012. PMID: 22919418. DOI: 10.1155/2012/718320

17 Mantilla JG, Ricciotti RW, Chen EY, Liu YJ and Hoch BL: Amplification of DNA damage-inducible transcript 3 (ddit3) is associated with myxoid liposarcoma-like morphology and homologous lipoblastic differentiation in dedifferentiated liposarcoma. Mod Pathol 32(4): 585-592, 2019. PMID: 304207 27. DOI: $10.1038 / \mathrm{s} 41379-018-0171-\mathrm{y}$

18 Dutto I, Tillhon M, Cazzalini O, Stivala LA and Prosperi E: Biology of the cell cycle inhibitor p21(cdkn1a): Molecular mechanisms and relevance in chemical toxicology. Arch Toxicol 89(2): 155-178, 2015. PMID: 25514883. DOI: 10.1007/s00204-014-1430-4

19 Ansems M, Sondergaard JN, Sieuwerts AM, Looman MW, Smid M, de Graaf AM, de Weerd V, Zuidscherwoude M, Foekens JA, Martens JW and Adema GJ: Dc-script is a novel regulator of the tumor suppressor gene $c d k n 2 b$ and induces cell cycle arrest in eralpha-positive breast cancer cells. Breast Cancer Res Treat 149(3): 693-703, 2015. PMID: 25663546. DOI: $10.1007 / \mathrm{s} 10549-015-3281-\mathrm{y}$

20 Kaneko M, Iwase I, Yamasaki Y, Takai T, Wu Y, Kanemoto S, Matsuhisa K, Asada R, Okuma Y, Watanabe T, Imaizumi K and Nomura Y: Genome-wide identification and gene expression profiling of ubiquitin ligases for endoplasmic reticulum protein degradation. Sci Rep 6: 30955, 2016. PMID: 27485036. DOI: 10.1038/srep30955

21 Italiano D, Lena AM, Melino G and Candi E: Identification of ncf2/p67phox as a novel p53 target gene. Cell Cycle 11(24): 4589-4596, 2012. PMID: 23187810. DOI: 10.4161/cc.22853

22 Wallot-Hieke N and Verma N: Systematic analysis of atg 13 domain requirements for autophagy induction. 14(5): 743-763, 2018. PMID: 29173006. DOI: 10.1080/15548627.2017.1387342

23 Wu H, Pang P, Liu MD, Wang S, Jin S, Liu FY and Sun CF: Upregulated mir20a5p expression promotes proliferation and invasion of head and neck squamous cell carcinoma cells by targeting of tnfrsf21. Oncol Rep 40(2): 1138-1146, 2018. PMID: 29901115. DOI: 10.3892/or.2018.6477

24 Li R, Dong J, Bu XQ, Huang Y, Yang JY, Dong X and Liu J: Interleukin-6 promotes the migration and cellular senescence and inhibits apoptosis of human intrahepatic biliary epithelial cells. 119(2): 2135-2143, 2018. PMID: 28857276. DOI: 10.1002/ jcb. 26375 
25 Im JY, Lee KW, Won KJ, Kim BK, Ban HS, Yoon SH, Lee YJ, Kim YJ, Song KB and Won M: DNA damage-induced apoptosis suppressor (ddias), a novel target of nfatc1, is associated with cisplatin resistance in lung cancer. Biochim Biophys Acta 1863(1): 40-49, 2016. PMID: 26493727. DOI: 10.1016/ j.bbamcr.2015.10.011

26 Swaffer MP, Jones AW, Flynn HR, Snijders AP and Nurse P: Cdk substrate phosphorylation and ordering the cell cycle. Cell 167(7): 1750-1761.e1716, 2016. PMID: 27984725. DOI: 10.1016/j.cell.2016.11.034

27 Chen D, Guo W, Qiu Z, Wang Q, Li Y, Liang L, Liu L, Huang S, Zhao Y and He X: Microrna-30d-5p inhibits tumour cell proliferation and motility by directly targeting ccne 2 in nonsmall cell lung cancer. Cancer Lett 362(2): 208-217, 2015 PMID: 25843294. DOI: 10.1016/j.canlet.2015.03.041

28 Perotti V, Baldassari P, Molla A, Vegetti C, Bersani I, Maurichi A, Santinami M, Anichini A and Mortarini R: Nfatc2 is an intrinsic regulator of melanoma dedifferentiation. Oncogene 35(22): 28622872, 2016. PMID: 26387540, DOI: $10.1038 /$ onc.2015.355

29 Wu X, Luo Q, Zhao P, Chang W, Wang Y, Shu T, Ding F, Li B and Liu Z: Josd1 inhibits mitochondrial apoptotic signalling to drive acquired chemoresistance in gynaecological cancer by stabilizing mcl1. 2019. PMID: 31043700, DOI: 10.1038/s41418019-0339-0

30 da Luz CM, da Broi MG, Donabela FC, Paro de Paz CC, Meola J and Navarro PA: Ptgs2 down-regulation in cumulus cells of infertile women with endometriosis. Reprod Biomed Online 35(4): 379-386, 2017. PMID: 28734688. DOI: $10.1016 /$ j.rbmo. 2017.06.021

31 Kesselring R, Glaesner J, Hiergeist A, Naschberger E, Neumann H, Brunner SM, Wege AK, Seebauer C, Kohl G, Merkl S, Croner RS, Hackl C, Sturzl M, Neurath MF, Gessner A, Schlitt HJ, Geissler EK and Fichtner-Feigl S: Irak-m expression in tumor cells supports colorectal cancer progression through reduction of antimicrobial defense and stabilization of stat 3 . Cancer Cell 29(5): 684-696, 2016. PMID: 27150039. DOI: 10.1016/j.ccell.2016.03.014

32 Yu X, Wang H, Li X, Guo C, Yuan F, Fisher PB and Wang XY: Activation of the mda-5-ips-1 viral sensing pathway induces cancer cell death and type $\mathrm{i}$ ifn-dependent antitumor immunity. Cancer Res 76(8): 2166-2176, 2016. PMID: 26893477. DOI: 10.1158/0008-5472.can-15-2142

33 Qian CC: The shanghan lun held by the cabinet of japan is not zhao kaimei's original edition. Zhonghua Yi Shi Za Zhi 40(6): 346-350, 2010. PMID: 21223704

34 Huang WW, Chiu YJ, Fan MJ, Lu HF, Yeh HF, Li KH, Chen PY, Chung JG and Yang JS: Kaempferol induced apoptosis via endoplasmic reticulum stress and mitochondria-dependent pathway in human osteosarcoma u-2 os cells. Mol Nutr Food Res 54(11): 1585-1595, 2010. PMID: 20564475. DOI: 10.1002/ mnfr.201000005

35 Li D, Dai C, Yang X, Li B, Xiao X and Tang S: Gadd45a regulates olaquindox-induced DNA damage and s-phase arrest in human hepatoma g2 cells via jnk/p38 pathways. Molecules 22(1), 2017. PMID: 28098804. DOI: 10.3390/molecules 22010124

36 Syc-Mazurek SB, Fernandes KA, Wilson MP, Shrager P and Libby RT: Together jun and ddit3 (chop) control retinal ganglion cell death after axonal injury. Mol Neurodegener 12(1): 71, 2017. PMID: 28969695. DOI: 10.1186/s13024-017-0214-8

37 Martindale JL and Holbrook NJ: Cellular response to oxidative stress: Signaling for suicide and survival. J Cell Physiol 192(1):
1-15, 2002. PMID: 12115731. DOI: 10.1002/jcp.10119

38 Fan Y, Lee TV, Xu D, Chen Z, Lamblin AF, Steller H and Bergmann A: Dual roles of drosophila p53 in cell death and cell differentiation. Cell Death Differ 17(6): 912-921, 2010. PMID: 19960025. DOI: 10.1038/cdd.2009.182

39 Barlev NA, Sayan BS, Candi E and Okorokov AL: The microrna and p53 families join forces against cancer. Cell Death Differ 17(2): 373-375, 2010. PMID: 20062068. DOI: 10.1038/cdd.2009.73

40 Xiong Y, Hannon GJ, Zhang H, Casso D, Kobayashi R and Beach D: P21 is a universal inhibitor of cyclin kinases. Nature 366(6456): 701-704, 1993. PMID: 8259214. DOI: 10.1038/ $366701 \mathrm{a} 0$

41 Grana X and Reddy EP: Cell cycle control in mammalian cells: Role of cyclins, cyclin dependent kinases (cdks), growth suppressor genes and cyclin-dependent kinase inhibitors (ckis). Oncogene 11(2): 211-219, 1995. PMID: 7624138.

42 Ponting CP, Oliver PL and Reik W: Evolution and functions of long noncoding rnas. Cell 136(4): 629-641, 2009. PMID: 19239885. DOI: 10.1016/j.cell.2009.02.006

43 Tani H, Onuma Y, Ito Y and Torimura M: Long non-coding rnas as surrogate indicators for chemical stress responses in humaninduced pluripotent stem cells. PLoS One 9(8): e106282, 2014. PMID: 25171338. DOI: 10.1371/journal.pone.0106282

44 Tani $\mathrm{H}$ and Torimura M: Identification of short-lived long noncoding rnas as surrogate indicators for chemical stress response. Biochem Biophys Res Commun 439(4): 547-551, 2013. PMID: 24036268. DOI: 10.1016/j.bbrc.2013.09.006

45 Voellenkle C, Garcia-Manteiga JM, Pedrotti S, Perfetti A, De Toma I, Da Silva D, Maimone B, Greco S, Fasanaro P, Creo P, Zaccagnini G, Gaetano C and Martelli F: Implication of long noncoding rnas in the endothelial cell response to hypoxia revealed by rna-sequencing. Sci Rep 6: 24141, 2016. PMID: 27063004. DOI: $10.1038 /$ srep24141

46 Liu K, Liu S, Zhang W, Ji B, Wang Y and Liu Y: Mir222 regulates sorafenib resistance and enhance tumorigenicity in hepatocellular carcinoma. Int J Oncol 45(4): 1537-1546, 2014. PMID: 25096647. DOI: 10.3892/ijo.2014.2577

47 le Sage C, Nagel R and Agami R: Diverse ways to control p27kip1 function: Mirnas come into play. Cell Cycle 6(22): 2742-2749, 2007. PMID: 17986865. DOI: 10.4161/cc.6.22.4900

48 Galardi S, Mercatelli N, Giorda E, Massalini S, Frajese GV, Ciafre SA and Farace MG: Mir-221 and mir-222 expression affects the proliferation potential of human prostate carcinoma cell lines by targeting p27kip1. J Biol Chem 282(32): 2371623724, 2007. PMID: 17569667. DOI: 10.1074/jbc.M701805200

49 Sun L, Guo C, Yuan H, Burnett J, Pan J, Yang Z, Ran Y, Myers I and Sun D: Overexpression of carboxypeptidase a4 (cpa4) is associated with poor prognosis in patients with gastric cancer. Am J Transl Res 8(11): 5071-5075, 2016. PMID: 27904708.

50 Ross PL, Cheng I, Liu X, Cicek MS, Carroll PR, Casey G and Witte JS: Carboxypeptidase 4 gene variants and early-onset intermediate-to-high risk prostate cancer. BMC Cancer 9: 69, 2009. PMID: 19245716. DOI: 10.1186/1471-2407-9-69

Received March 19, 2019

Revised May 14, 2019

Accepted May 15, 2019 